\title{
Oral Myoma Vaccine V3-myoma
}

National Cancer Institute

\section{Source}

National Cancer Institute. Oral Myoma Vaccine V3-myoma. NCI Thesaurus. Code C158745.

An orally available therapeutic myoma vaccine containing pooled antigens derived from hydrolyzed, inactivated blood and tumor tissue samples from patients with uterine myoma, with potential antineoplastic and immunomodulatory activities. Upon oral administration, V3-myoma may stimulate the immune system to mount a cytotoxic $T$ lymphocyte-mediated response against cells expressing myoma-associated antigens. This may reduce the myoma growth and improve myoma-related symptoms. 